1) 補液：リンゲル $20 \mathrm{ml} / \mathrm{kg}$, 強肝剂, 総合ビタ ソ…導入 40 分前

2) 前処置剤 : コンベレン $0.05 \mathrm{ml} / \mathrm{kg} \cdots$ 導入 10 分前

3) 救急用器具：不慮の事故に対応できるように酸 素, 心電計, 強心剂, 呼吸促進剂等の準備

4) 手術室の室温確保 : $20^{\circ} \mathrm{C} \sim 25^{\circ} \mathrm{C}$ 。

5) 新生児の蘇生器の準備（保温, 酸素)

3. 麻酔方法と麻酔経過

1）局所麻酔の場合（衰弱強度の場合）

術部を剪毛・消毒した後， $2 \%$ 塩酸プロカインを皮 下, 腹筋に注入。

2）全身麻酔の場合（大・中型犬, 咬癖犬, 猫）

前処置剂投薬 10 分後に塩酸ケタミン（犬 : $5 \mathrm{mg} / \mathrm{kg}$, 猫 : $10 \mathrm{mg} / \mathrm{kg}$ ) を $\mathrm{IM}_{\text {。 }}$

3）エーテル麻酔（全身麻酔が覚醒し始めた際）エー テル濃度 $40 \sim 50 \%$ 断続的導入。

注 : 新生児摘出後に使用。

\section{4. 麻酔中および麻酔後の管理}

1) 保温：室温の確保，保温マットの使用。

2) 点滴：衰弱が著しい場合。

3) 薬剂の投与 : 必要に応じ止血剂, 強心剂, 抗生剂 等。

\section{イヌ・ネコの帝王切開手術における麻酔方法}

\section{木原滋陽（大分県開業）}

\section{1. 麻酔前の管理}

帝王切開の多くは，前もって絶食等の処置のできない 救急のものであるために，麻醉前の管理は殆んどできな い。採食飲水は無いのが通常であるが，禀告を聞くとと もに必要によっては胃カテーテルによって確認する。臨 床所見の確認は他の外科手術前之同様。長期在胎例, 胎 児の死亡, 腐敗等の場合も当然通常の検査, 確認, 補液 等の必要処置を行う。補液は通常 1 号液を用いる。

\section{2. 麻酔の前投薬}

胎児生存のものでは鎮静剤のアセプロマジン，クロー ルプロマジンその他の薬剤は用いない。硫酸アトロピン は年齢, 体重を考慮するが, 子宮内容の推定重量を差引い て $0.04 \mathrm{mg} / \mathrm{kg}$ を 20 分前に皮下または笳肉に用いる。

\section{3. 麻酔方法と麻酔経過}

麻酔は GOF。導入はマスク法。胎児への麻酔薬の影 響を少なくするには，導入から摘出までの㭙間を短くす るにあるので，剃毛等は麻酔前に行ら。通常この手術は 15 分前後で終るので, 胎児摘出までは 10 分以下の短時 間のため胎児への影響は殆んどない。マスクは大小，長
短など各種のものを 20 種類ばかり作ってあれば, ぞの ような犬猫にも適合するものがある。短頭種, 肥満など には気管チューブを插入するが，マスクのみで終るもの 头多い。

\section{4. 麻酔中および麻酔後の管理}

麻酔深度はなるべく浅く, 痛覚のない程度にするが, 胎児摘出終了前から子宮縫合のころには一応麻酔深度を 浅くして，子宮の収縮を促がす。麻酔中は患畜によって 補液は 1 号および乳酸加リンゲルを用いる。その他患畜 の症状によって対応する。

\section{5. 麻酔中のモニターリング}

術前のチェックで異常のみられないものでは, 呼吸お よび心拍数のみ, 必要に応じて心電図をモニターしてお く。レスピレーターには直ちに接続できる準備をととの えておく。心電図はモニターと共に 6 連の心電図を用い る。

\section{イヌ・ネコの帝王切開手術における麻酔方法}

\section{桑島 功 (千葉県開業)}

\section{1. 麻酔前の管理}

1) 現症と合併症の把握 :

a. 患畜とカルテの確認 : 畜主氏名, 患畜の種類, 品 種, 体重, 名号など。

b. 妊娠経過と現在の所見の確認: 出産回数, 以前の 分婏状態 (自然分婏, 帝王切開), 交配日, 現在までの 異常の有無, 陣痛の状態など。

c. $\mathrm{X}$ 線検查 : 母体および胎児の状態の確認。頭数, 体位, 発育状態, 奇形の有無など。

d. 使用薬剤の確認。

e. その他麻酔前に気づいたと全て。

2) 絶食 : 手術前 12 時間（但し緊急の場合を除く）。

3）麻酔前の T.P.R.。

\section{2. 麻酔の前投薬}

必要に応じて抗ヒスタミン剂, 止血剂, 抗生剂などの 投与。

3. 麻酔方法と麻酔経過

1) 導入 : 1 . 硫酸アトロピン $0.05 \mathrm{mg} / \mathrm{kg} \mathrm{IV}$ 2. ドロペリドール $0.25 \mathrm{mg} / \mathrm{kg} \mathrm{IV}$ 3. 塩酸ケタミン $0.50 \mathrm{mg} / \mathrm{kg} \mathrm{IV}$

以上 3 種を混注する。

導入直後に十分に酸素を吸入させる。

2) 維持: OF

維持 フローセン濃度 $1 \sim 2 \%$ （可能な限り低濃度で 維持)。 
Poor risk では, フローセンのマスクによる導入を行 5 。

4. 麻酔中および麻酔後の管理

1) 保温：導入直後より覚醒まで。

2）点滴：導入直後より覚醒まで，必要に応じて。通 常は, 乳酸加リンゲル液。

3）モニターリング：覚醒まで麻酔中のモニターを続 ける。

4) ICU：重症例に対して, 温度, 湿度, 必要に応じ, 薬凧の投与, 酸素の推送を行う。

5）薬剂の投与：必要に応じて止血剤, 子宮収縮剤, 抗生剂, 強心剂, 利尿剂など。

6）仔犬：正常呼吸の確認, 奇形の有無, 母犬が覚醒 するまで保温に注意する。

5. 麻酔中のモニターリング

1) T.P.R.

2) ECG

3) 酸素流量

4) フローセン濃度

5) 輸液量

6）瞳孔の大きさ，眼球の位置

7) 反射（眼瞼反射, 疼痛反射）

8）筋の緊張度

9）毛細血管再充満時間

10）粘膜の色調

6. ネコの帝王切開手術における麻酔法

1) 麻酔前の管理 : 犬に準ずる

2）麻酔の前投薬：硫酸アトロピン $0.025 \mathrm{mg} / \mathrm{kg} \mathrm{SC}$ その他犬に準ずる。

3）麻酔方法と麻酔経過

a. 塩酸ヶタミン: 10〜20 mg/kg (IM)

b. 維持 OF $1 \sim 2 \%$ (必要に応じて)

4）麻酔中および麻酔後の管理：犬に準ずる。

当院においては, 猫の難産は, 犬に比べて非常に少な く, 帝王切開術を必要とする症例は, 年間数例程度であ る。

\section{イヌ・ネコの開胸手術における麻酔方法}

原崇（名古屋市開業）

\section{1. 麻酔前の管理}

1) 症例に関するデーターの収集と検討

2) 手術目的と手術手順の検討と機械の準備

3）麻酔剤と麻酔方法の検討

(1) 前投薬の選択
(2) 吸入麻酔の場合

(1). ガスの選択 (GO. GOF. OF. OE.)

(口. 回路の選択 (閉鎖循環・半閉鎖・開放)

(3) 非吸入麻酔の場合

(1). 塩酸ケタミン微量点滴

(口).サクシニルコリンクロライド（ネコには使用しな ()

(の. (1)と(口)組合せ

4) 呼吸管理の検討

（1）平常呼吸時での一息換気量および分時換気量の測 定

（2）人工呼吸方法の選狤，用手か自動かまたは双方の 配分

(3) レスピレーターのセッティング（酸素流量調節） ズル，ェアーバッグ，蛇管の太さ，長さ）

(4) 人工呼吸時の送気内容（酸素のみか, 酸素之空気 混合か)

5）輸血または輸液の検討

6) 緊急処置ならびに緊急薬剂の準備

7) 手術前 20 時間絶食

8）前投薬開始前からテレィーターによる ECG 監視 （前投薬に対する反応）

9）麻酔直前の T.P.R.

2. 麻酔の前投菜

1）硫酸アトロピン $0.02 \sim 0.05 \mathrm{mg} / \mathrm{kg} \mathrm{SC}$ または IM 導入 30 分前

2）鎮静剤の投与（症例により選択適用）

(1) クロールプロマジン $0.5 \sim 2 \mathrm{mg} / \mathrm{kg} \mathrm{IM}$ 麻酔開始 30 分前

(2) アセプロマジン $0.1 \sim 0.3 \mathrm{mg} / \mathrm{kg} \mathrm{IM}$

(3) プロピオニールプロマジン $0.01 \mathrm{mg} \mathrm{IM} \mathrm{\prime \prime}$

120 分前（ネコには使用しない）

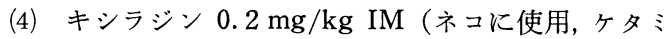
ン麻酔の場合）房室伝導抑制があれば使用しない

3. 麻势方法と麻酔経過

1) 吸入麻酔

(1) 導入：サイアミラール 気管挿管ができるまで

（2）気管確保：気管チューブ挿管（必ず適合サイズを 選ぶ)

（3）静脈確保 : 中心静脈圧測定カニューレ装着（静脈 内投与はここから）

（4）酸素の吸入：気管チューブを通して酸素の吸入

(5) サイアミラール効果が減弱してから $\mathrm{O}_{2} 4 \mathrm{l} /$ 分, $\mathrm{N}_{2} \mathrm{O} 25 \sim 30 \%, \mathrm{~F} 4 \%$ で導入

（6）維持：開胸をではベインサーキットを使用し，自 